\title{
SISTEM PENDUKUNG KEPUTUSAN DENGAN MENERAPKAN METODE ELECTRE DALAM MENENTUKAN PRIORITAS CALON DEBITUR
}

\author{
${ }^{[1]}$ Cahya Rahmad, ${ }^{[2]}$ Dimas Wahyu Wibowo, ${ }^{[3]}$ Pramana Yoga Saputra \\ ${ }^{[1],[2],[3]}$ Politeknik Negeri Malang
}

\begin{abstract}
Abstrak:Pinjaman dana tunai adalah fasilitas yang disediakan oleh PT. NSC Finance untuk konsumen melakukan pinjaman dengan jaminan BPKB Motor. Proses pengolahan pinjaman dana tunai di proses bagian marketing, survei, dan administrasi. Data yang dikelola adalah berkas pengajuan, surat perjanjian pinjaman dana tunai, motor diasuransikan, hasil survei, jumlah pinjaman, angsuran pinjaman dan pembayaran angsuran. Laporan yang diproses dalam pinjaman dana tunai adalah laporan berkas pengajuan, laporan angsuran konsumen, isi perjanjian pembayaran dan laporan motor yang digunakan. Proses input data dilakukan oleh admin atau Credit Marketing Suvervisor (CMS). Jika salah satu syarat tidak terpenuhi maka secara otomatis sistem akan menolak pengajuan pinjaman dana, sehingga dapat mengganggu pemasukan perusahaan. Oleh sebab itu, diperlukan sistem pendukung keputusan yang dapat membantu perusahaan dalam mengambil keputusan. Dengan menggunakan Sistem Pendukung Keputusan menggunakan ELECTRE diharapkan dapat mempermudahkan perusahaan dalam menentukan prioritas pinjaman dana kepada nasabah.
\end{abstract}

Kata kunci: Fuzzy, NSC, Sistem Pendukung Keputusan.

\section{Pendahuluan}

Sistem Pendukung Keputusan (SPK) adalah sistem yang membantu pengambilan keputusan dengan melengkapi berbagai informasi dari data yang telah diolah secara relevan yang diperlukan untuk membuat keputusan tentang suatu masalah dengan cepat dan akurat. Sistem ini tidak dimaksudkan untuk menggantikan pengambilan keputusan dalam proses pembuatan keputusan (Kusrini, 2007). Menurut Subakti (2002), komponen sistem pendukung keputusan yaitu (1) Data Management (Manajemen Data), (2) Model Management (Manajemen Model), (3) Communication (dialog subsistem), dan (4) Knowledge Management (Manajemen Pengetahuan).

Menurut Janko dan Bernoider (2005), Electre merupakan salah satu metode pengambilan keputusan multikriteria berdasarkan pada konsep outranking dengan menggunakan perbandingan berpasangan dari alternatif-alternatif berdasarkan setiap 
kriteria yang sesuai. Metode Electre digunakan pada kondisi dimana alternatif yang kurang sesuai dengan kriteria dieliminasi, dan alternatif yang sesuai dapat dihasilkan. Dengan kata lain, Electre digunakan untuk kasus-kasus dengan banyak alternatif, tetapi hanya sedikit kriteria yang dilibatkan. Suatu alternatif dikatakan mendominasi alternatif yang lainnya jika satu atau lebih kriterianya melebihi (dibandingkan dengan kriteria dari alternatif yang lain) dan sama dengan kriteria lain yang tersisa (Kusumadewi dkk, 2006).

Langkah-langkah yang dilakukan dalam penyelesaian masalah menggunakan metode Electreadalah sebagai berikut.

\section{Normalisasi Matrik Keputusan.}

Electre dimulai dari membentuk tabel rating kecocokan, yaitu perbandingan berpasangan setiap alternatif pada setiap kriteria $\left(X_{i j}\right)$. Nilai ini harus dinormalisasikan ke dalam suatu skala yang dapat diperbandingkan $\left(r_{i j}\right)$, sehingga dapat dituliskan pada persamaan 1:

$$
\begin{aligned}
& r_{i j}=\frac{X_{i j}}{\sqrt{\sum_{i=1}^{m} D^{2} i j}} \ldots \ldots \ldots \ldots \ldots \ldots \ldots \ldots \ldots \ldots \ldots \ldots \ldots \\
& \text { Ket }: \\
& X=\text { Bilangan ternormalisasi } \\
& i=1,2,3, m \\
& j=1,2,3, n
\end{aligned}
$$

\section{Menentukan Tabel V}

Selanjutnya pengambilan keputusan harus memberikan faktor kepentingan (bobot) pada setiap kriteria yang mengekspresikan kepentingan relatifnya (Wi), sehingga dapat dituliskan pada persamaan:

$$
\begin{aligned}
& W=(w 1, w 2, \ldots \ldots \ldots \ldots w n) \\
& \text { Dengan } \sum_{i=1}^{n} w_{i}=1
\end{aligned}
$$

Bobot ini selanjutnya dikalikan dengan matriks perbandingan berpasangan membentuk metrik $\mathrm{V}$, sehingga dapat dituliskan pada persamaan:

$$
V_{i j}=W_{j} X_{i j}
$$

\section{Menentukan Corcondance dan Discordance Index}

Pembentukan corcondance index dan discordance index untuk setiap pasangan alternatif dilakukan melalui taksiran terhadap relasi perangkingan. Untuk 
setiap pasangan alternatif $A_{k}$ dan $A_{1}\left(\mathrm{k}, 1=1,2, \ldots, \mathrm{m}\right.$ dan $\left.k^{1} l\right)$, matriks keputusan untuk kriteria j, terbagi menjadi 2 himpunan bagian. Pertama, himpunan corcondance index $\left\{C_{k l}\right\}$ menunjukan penjumlahan bobot-bobot kriteria yang mana alternatif $A_{k}$ lebih baik daripada alternatif $A_{1}$, sehingga dapat dituliskan pada persamaan 2.4.

$$
C_{k l}=\left(j \mid V_{k j} \geq V_{i j}\right)
$$

untuk $\mathrm{j}=1,2, \ldots \ldots, \mathrm{n}$

Kedua, himpunan corcondance index $\left\{d_{k l}\right\}$ diberikan sebagai berikut sehingga dapat dituliskan pada persamaan 2.5.

$D_{k l}=\left(j \mid V_{k j} \leq V_{i j}\right)$

Untuk $\mathrm{j}=1,2, \ldots \ldots, \mathrm{n}$

\section{Menghitung nilai C dan D tiap alternatif}

Setelah dibandingkan berdasarkan concordance dan discordanceindex, selanjutnya akan dihitung total nilai $\mathrm{C}$ dan $\mathrm{D}$ berdasarkan bobot preferensi yang dimilikinya. Selanjutnya perangkingan akan dilihat dari selisih nilai $C$ dan $D$ pada alternatf. Alternatif dengan nilai yang terbesar akan mendapat rangking paling atas. PT. Nusa Surya Ciptadana merupakan lembaga pembiayaan kendaraaan bermotor yang merupakan bagian dari Nusantara Group didirikan pada tahun 2000 serta disahkan oleh Menteri Kehakiman Republik Indonesia pada 27 April 2001. PT. Nusa Surya Ciptadana memiliki cabang di 93 lokasi yang tersebar di 28 propinsi di Indonesia. NSC Finance mulai Agustus 2004 membiayai mayoritas kredit di AuthorizedDealer sepeda motor Honda PT Nusantara Sakti dan PT Nusantara Surya Sakti yang merupakan "Sister Company" yang mempunyai cabang di 91 kota yang tersebar di seluruh wilayah Indonesia. NSC Finance mempunyai pangsa pasar sendiri yang 'captive' karena tergabung dalam group dealer sepeda motor sehingga dengan layanan satu atap ini akan mewujudkan konsep Nusantara Group berupa 3T yaitu Tercepat, Termudah, dan Terpercaya dalam bidang Kepemilikan Kendaraan Bermotor. NSC Finance didukung oleh direksi PT. Nusantara Sakti dan PT. Nusantara Surya Sakti yang berpengalaman dalam penjualan sepeda motor sejak tahun 1962 dan pembiayaan sepeda motor sejak tahun 1984.

Salah satu cabang NSC Finance terdapat di Malang beralamat jalan Soekarno Hatta no. D510 Malang. Untuk kantor NSC Finance terdapat pada lantai 2, sedangkan pada lantai 1 merupakan kantor dari NSS dealer. Konsumen yang akan meminjam dana tunai dapat menuju kantor NSC pada lantai 2. Untuk Proses 
pinjaman dana dilakukan survei terlebih dahulu ke rumah konsumen dan melakukan cek lingkungan untuk mengetahui informasi calon debitur. Setelah proses cek lingkungan selesai maka data dari petugas survei akan diserahkan ke admin untuk diinput berdasarkan hasil dari cek lingkungan petugas survei. Untuk selama ini hasil keputusan diterima atau tidaknya calon debitur untuk mengajukan pinjaman dana hanya berdasarkan lapangan. Sistem hanya untuk memasukkan data tanpa adanya sistem pendukung keputusan untuk membantu perusahaan dalam menentukan calon debitur.

Berdasarkan permasalahan tersebut diperlukan sistem pendukung keputusan yang dapat membantu perusahaan dalam mengambil keputusan. Dengan menggunakan sistem pendukung keputusan dengan logika Fuzzy diharapkan dapat membantu perusahaan dalam menentukan prioritas pinjaman dana kepada calon nasabah.

\section{A. Desain Sistem}

\section{Metode Penelitian}

\section{Analisa Kebutuhan Sistem}

Pada sistem ini, user dapat memasukan sendiri masukan data masing-masing parameter sesuai dengan range yang telah disediakan oleh sistem. Sistem akan memproses data input untuk dikelompokkan sesuai fungsi keanggotaan dan rule yang telah ditentukan.

a. Kebutuhan Input

Kebutuhan input sistem terdiri dari: Status Rumah, penghasilan, dan Jenis_Pekerjaan.

b. Kebutuhan Output

Output sistem berupa rekomendasi nama calon debitur yang berhak mendapatkan pinjaman.

\section{Diagram Use Case}

Use case merupakan sebuah teknik yang digunakan dalam pengembangan sistem pendukung keputusan menggunakan metode Electre untuk mendapatkan kebutuhan fungsional dari sistem. Pada use case ini akan menjelaskan interaksi yang terjadi antara 'aktor'-'inisiator' dari sistem pendukung keputusan ini. Diagram Use Case untuk sistem pendukung keputusan menggunakan metode electre seperti pada gambar 1. 


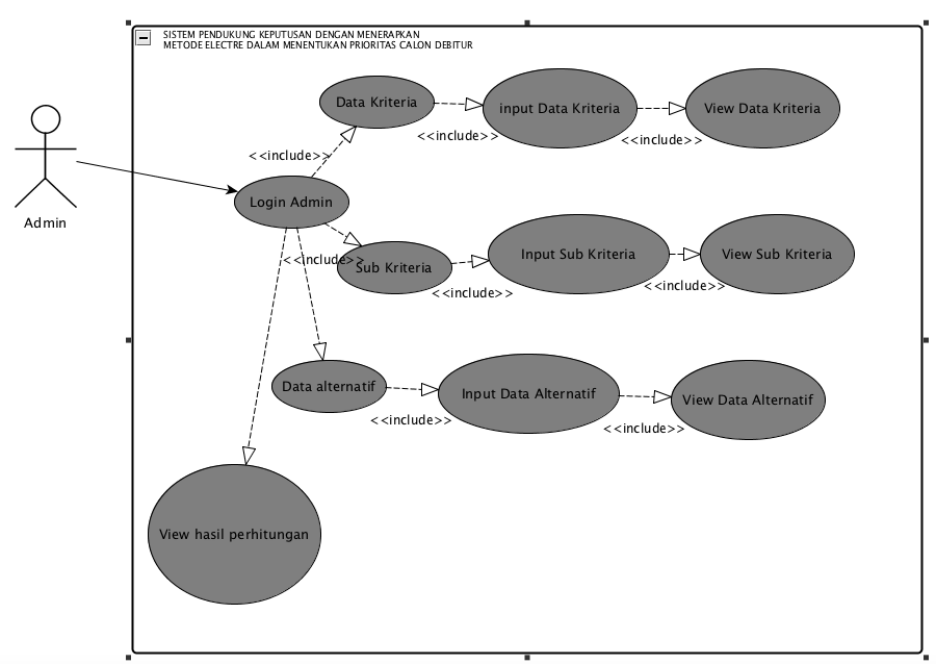

Gambar 1. Diagram Use Case

\section{Skenario Use Case}

Pada bagian ini akan secara detail dari masing-masing use case yang digunakan dalam perancangan

\section{a. Skenario Use case memasukkan Kriteria}

\begin{tabular}{l|l}
\multicolumn{1}{c|}{ Admin } & \multicolumn{1}{c}{ Sistem } \\
\hline 1. Login admin & $\begin{array}{l}\text { 2. Sistem mengklarifikasi username } \\
\text { dan password yang dimasukkan }\end{array}$ \\
$\begin{array}{l}\text { 2. Memasukkan data Kriteria } \\
\text { 3. Memasukkan data kriteria } \\
\text { berserta bobot nilainya }\end{array}$ & $\begin{array}{l}\text { Klik Buttton simpan } \\
\text { Menampilkan ke halaman Data } \\
\text { Kriteria kategori }\end{array}$
\end{tabular}


b. Skenario use case memasukkan Sub Kriteria

\begin{tabular}{l|l}
\multicolumn{1}{c|}{ Admin } & \multicolumn{1}{c}{ Sistem } \\
\hline 1. Login admin & $\begin{array}{l}\text { 2. Sistem Mengklarifikasi username } \\
\text { dan password yang dimasukkan }\end{array}$ \\
3. Memilih sub kriteria & $\begin{array}{l}\text { 4. Menampilkan kriteria yang telah } \\
\text { dimasukkan pada halaman kriteria }\end{array}$ \\
$\begin{array}{l}\text { 5. Menginputkan data sub kriteria } \\
\text { berserta bobot nilainya }\end{array}$ & $\begin{array}{l}\text { 6. Klik tombol Simpan } \\
\text { Sub Kriteria }\end{array}$
\end{tabular}

c. Skenario Use case memasukkan Data Alternatif

\begin{tabular}{l|l}
\multicolumn{1}{c|}{ Admin } & \multicolumn{1}{c}{ Sistem } \\
\hline 1. Login admin & $\begin{array}{l}\text { 2. Sistem Mengklarifikasi username } \\
\text { dan password yang dimasukkan }\end{array}$ \\
$\begin{array}{l}\text { 3. Memilih Alternatif } \\
\begin{array}{l}\text { 4. Memasukkan data alternatif : } \\
\text { nama, jenis kelamin, alamat, status } \\
\text { rumah, penghasilan, jenis pekerjaan. } \\
\text { 5. Klik tombol simpan }\end{array}\end{array}$ & \\
& 6. Menampilkan ke halaman Altenatif
\end{tabular}

\section{Data Flow Diagram}

Data Flow Diagram (DFD) menggambarkan aliran data yang terjadi di dalam sistem, sehingga dengan dibuatnya DFD ini akan terlihat arus data yang mengalir dalam sistem.

\section{a. Context Diagram}

Dalam context diagram dari sistem penerapan metode electre dalam menentukan prioritas pinjaman dana tunai kepada nasabah. Masukan pada sistem tersebut serta hasil yang diperoleh user sebagai entity berbeda. Admin memberikan masukan berupa data kriteria, sub kriteria dan altenatif, kemudian sistem akan mengolah data-data tersebut untuk menghasilkan perengkingan menggunakan metode Electre. Untuk lebih detailnya dapat dilihat pada gambar 2. 


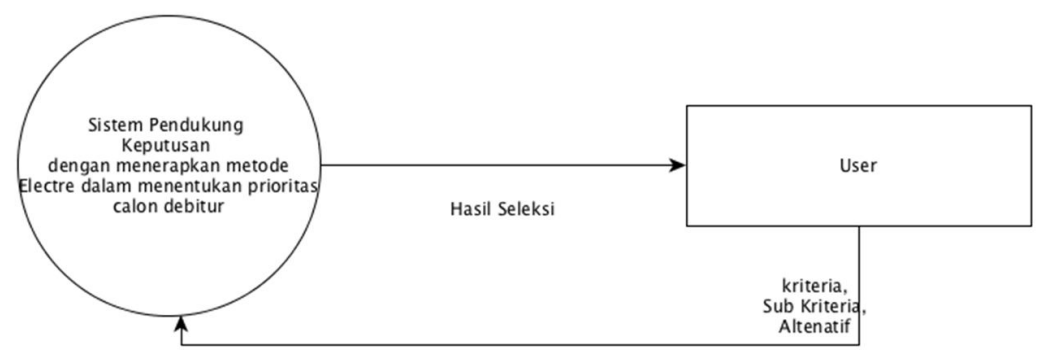

Gambar 2. Context Diagram

\section{b. Data Flow Diagram Level 1}

DFD level 1 dari sistem penerapan metode Electre dalam menentukan prioritas pinjaman dana tunai kepada nasabah adalah decompose dari ContextDiagram yang menjelaskan secara terperinci tentang proses yang ada di dalam sistem tersebut. Proses-proses tersebut yaitu proses perhitungan menggunakan metode electre. Untuk lebih jelasnya dapat dapat dilihat pada gambar 3

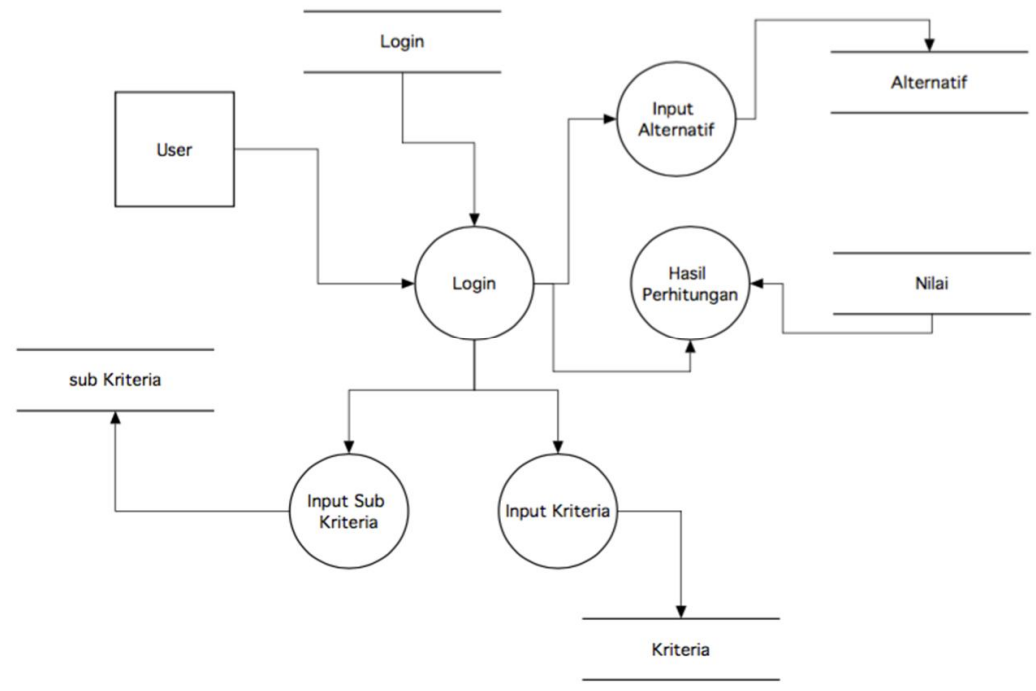

Gambar 3 DFD Level 1

\section{Konsep Pembentukan Database}

Pembentukan database ini mempunyai lima tabel yaitu kriteria, sub kriteria, altenatif, nilai dan tabel user. Pada tabel kriteria digunakan untuk menyimpan 
kriteria-kriteria yang digunakan untuk perhitungan. Pada tabel sub kriteria digunakan untuk menyimpan data-data sub pada masing-masing kriteria. Pada tabel alternatif digunakan menyimpan data-data alternatif. Pada tabel nilai digunakan untuk menyimpan hasil perhitungan yang nantinya akan dirangkingkan pada sistem. Sedangkan pada tabel user digunakan untuk menyimpan username dan password dari user.

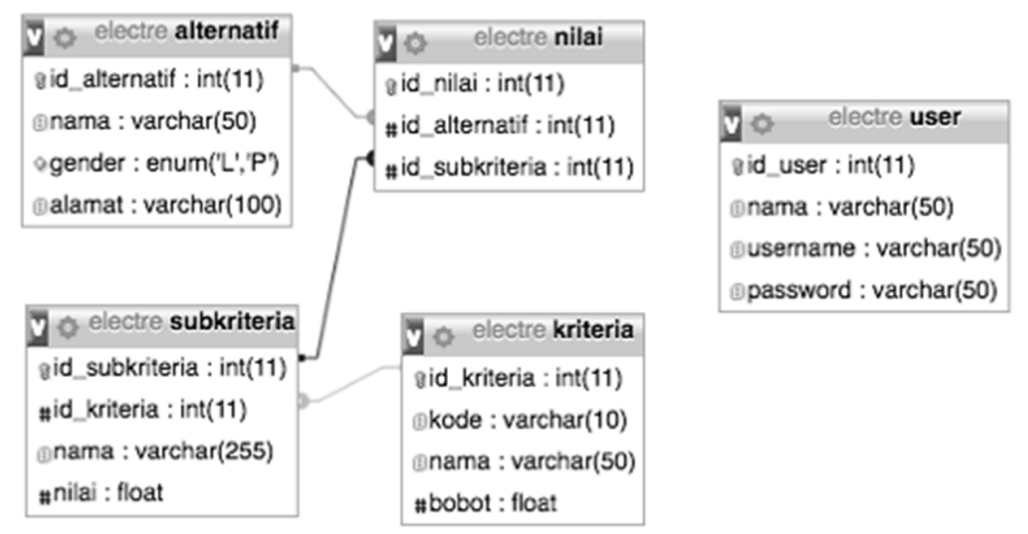

Gambar 5 Struktur tabel pada database electre

\section{Pengujian Sistem}

Pengujian sistem diperlukan untuk melihat kualitas dan kemampuan sistem dalam menerapkan metode electre. Adapun kriteria-kriteria yang digunakan untuk mendukung sistem antara lain sebagai berikut.

1. Status Rumah
a. Milik sendiri
b. Milik keluarga
c. Dinas atau kontrak

2. Penghasilan
a. Dibawah 1 juta
b. Diantara 1-3 juta
c. Diatas 3 juta

3. Jenis Pekerjaan
a. Pegawai Negeri
b. Pegawai Swasta
c. Lain-Lain: Wiraswasta, profesi 


\section{HASIL DAN PEMBAHASAN}

Bab ini merupakan hasil dan pembahasan sistem penerapan metode Electre dalam menentukan prioritas pinjaman dana tunai kepada nasabah. Proses melakukan identifikasi dilakukan dengan melaksanakan penelitian dan observasi pada sistem yang sedang berjalan. Hasil penelitian-penelitian tersebut dipergunakan untuk masukan ke dalam sistem yang akan dikembangkan.

\section{A. Antar Muka Pengguna}

Antar muka pengguna digunakan untuk memudahkan user dalam melakukan operasi perhitungan. Pada antar muka ini akan dijabarkan di beberapa bagian yang akan digunakan oleh user.

\section{Halaman Utama}

Pada Halaman utama terdapat judul penelitian dan beberapa Informasi tentang penelitian, penjelasan tentang Electre pada tab Informasi dan Login untuk admin.

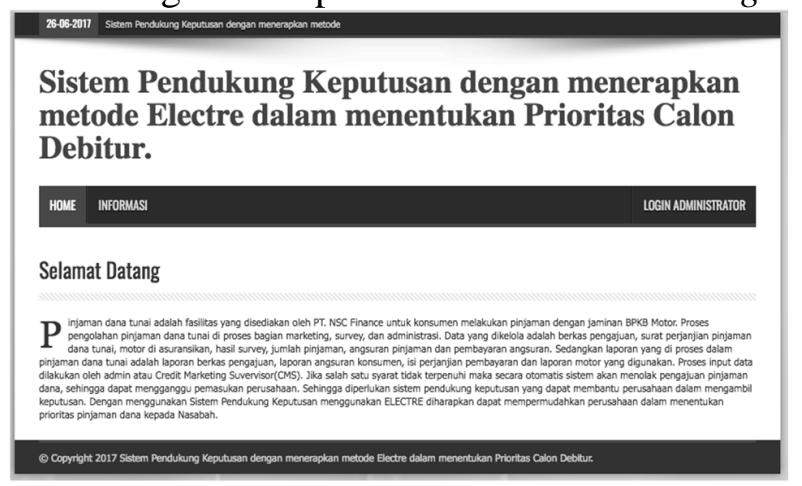

\section{Gambar 6 Halaman Home}

Pada halaman Informasi terdapat keterangan tentang metode Electre yang digunakan didalam penelitian ini.

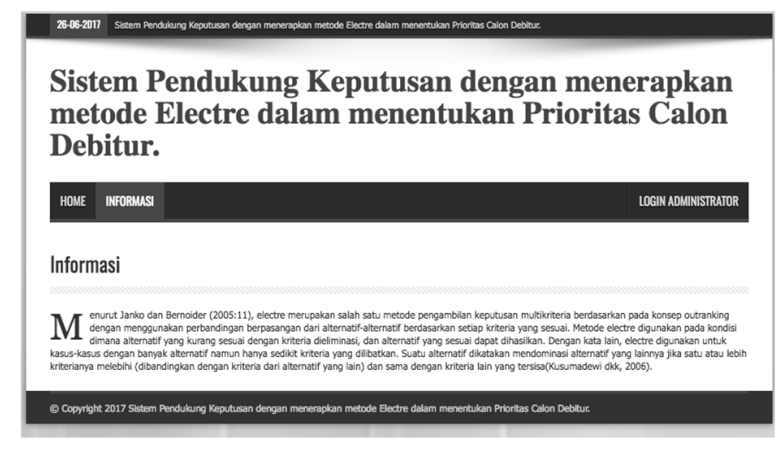

Gambar 7 Halaman Informasi 
Selain terdapat beberapa informasi tentang penelitian dan informasi tentang metode yang digunakan terdapat juga menu untuk login admintrator. Untuk menggunakan perhitungan menggunakan metode electre user diwajibkan untuk melakukan login terlebih dahulu.

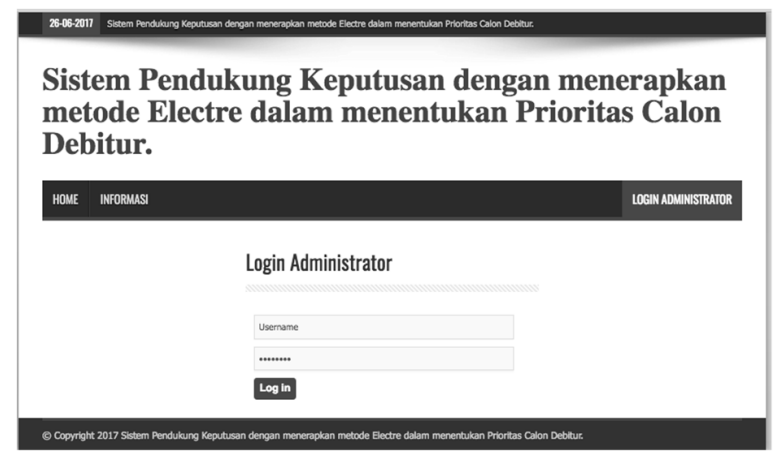

Gambar 8 Halaman Login Admin

\section{Halaman Utama User}

Halaman useradmin terdapat menu-menu untuk mengolah data antara lain : home, Kriteria, Sub kriteria, Alternatif dan Hasil Seleksi di mana di masing-masing menu ini terdapat fungsi-fungsi yang berbeda.

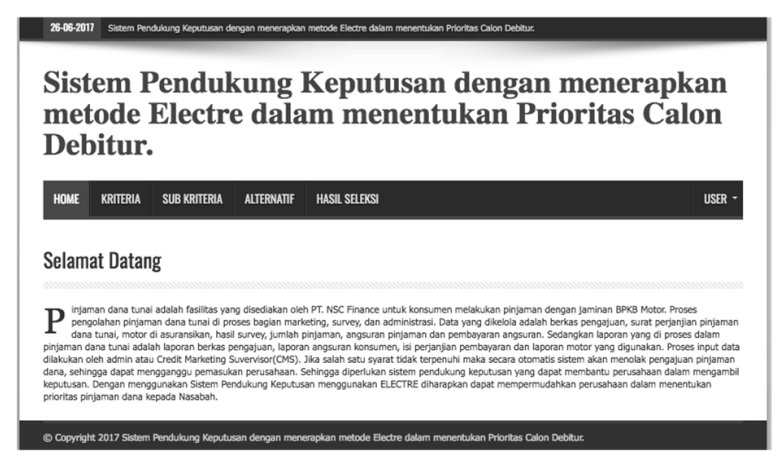

Gambar 9 Halaman Utama useradmin

\section{Halaman Kriteria}

Pada halaman kriteria user dapat menginputkan kriteria-kriteria yang akan digunakan dalam perhitungan. Pada penelitian ini kriteria yang digunakan adalah status rumah, penghasilan, jenis pekerjaan dimana memiliki bobot status rumah mempunyai bobot 4, penghasilan bobot mempunyai bobot 3 dan jenis pekerjaan mempunyai bobot 3. Jika user akan menambahkan kriteria baru maka user dapat melakukan proses input data dengan cara memilih tombol input baru, sedangkan jika 
user akan melakukan proses perubahan data atau penghapusan data maka user dapat memilih tombol edit atau delete pada masing-masing kriteria.

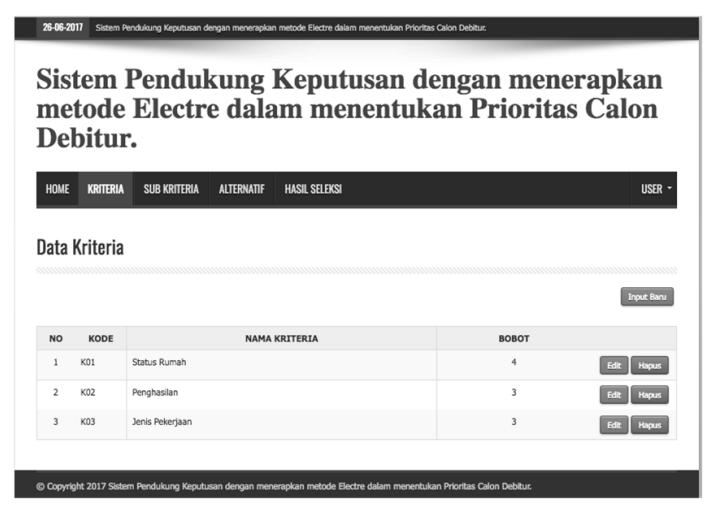

\section{Gambar 10 Halaman Kriteria}

\section{Halaman Sub Kriteria}

Pada Halaman ini, user memiliki sub kriteria pada masing-masing kriteria maka user dapat memasukkan data pada halaman sub kriteria. Pada penelitian ini, terdapat sub-sub kriteria pada kriteria yang telah ditentukan dihalaman kriteria. Sub kriteria ini antara lain status rumah mempunyai sub kriteria adalah dinas atau kontrak dengan nilai 1, milik keluarga dengan nilai 2 dan milik sendiri dengan nilai 3 . Untuk kriteria penghasilan terdapat juga sub-sub kriteria antara lain dibawah 1 juta mempunyai nilai 1, diantara 1-3 juta mempunyai nilai 2 dan diatas 3 juta mempunyai nilai 3. Dan untuk kriteria jenis pekerjaan mempunyai sub-sub kriteria antara lain wiraswasta/profesi mempunyai nilai 1 , pegawai swasta mempunyai nilai 2 dan pegawai negeri mempunyai nilai 3. User dapat melakukan proses input data baru dengan memilih tombol input baru selain itu user dapat juga melakukan proses edit data dan hapus data dengan memilih tombol edit dan hapus pada masing-masing sub kriteria.

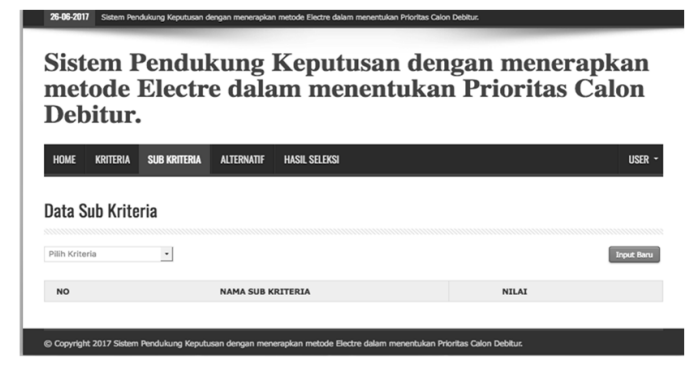

Gambar 11 Halaman utama sub kriteria 
Gambar 11 merupakan gambar halaman utama sub kriteria yang dimana user belum memasukkan data pada sub-sub kriteria. Sedangkan pada gambar... user telah memasukkan data pada sub kriteria pada kriteria status rumah.

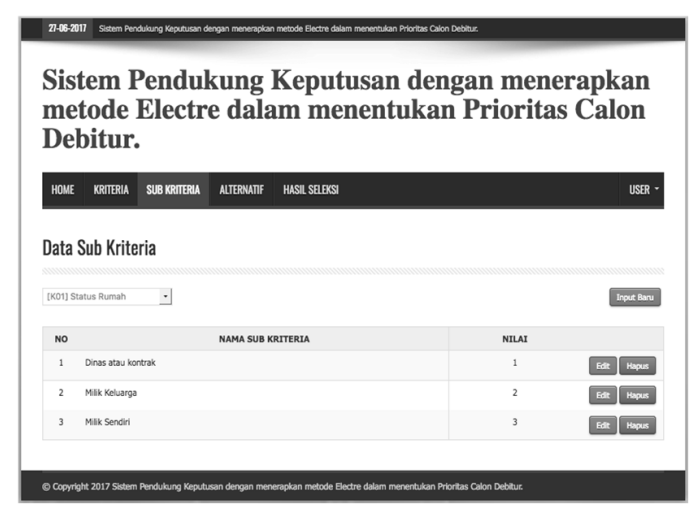

Gambar 12 Halaman sub kriteria pada kriteria status rumah

\section{Halaman Data Alternatif}

Pada halaman data alternative user dapat memasukkan data-data alternatif calon debitur yang akan dihitung dengan metode electre. User dapat memasukkan data dengan memilih tombol input baru. Selain itu user dapat juga melakukan proses edit dan delete pada masing-masing data alternatif.

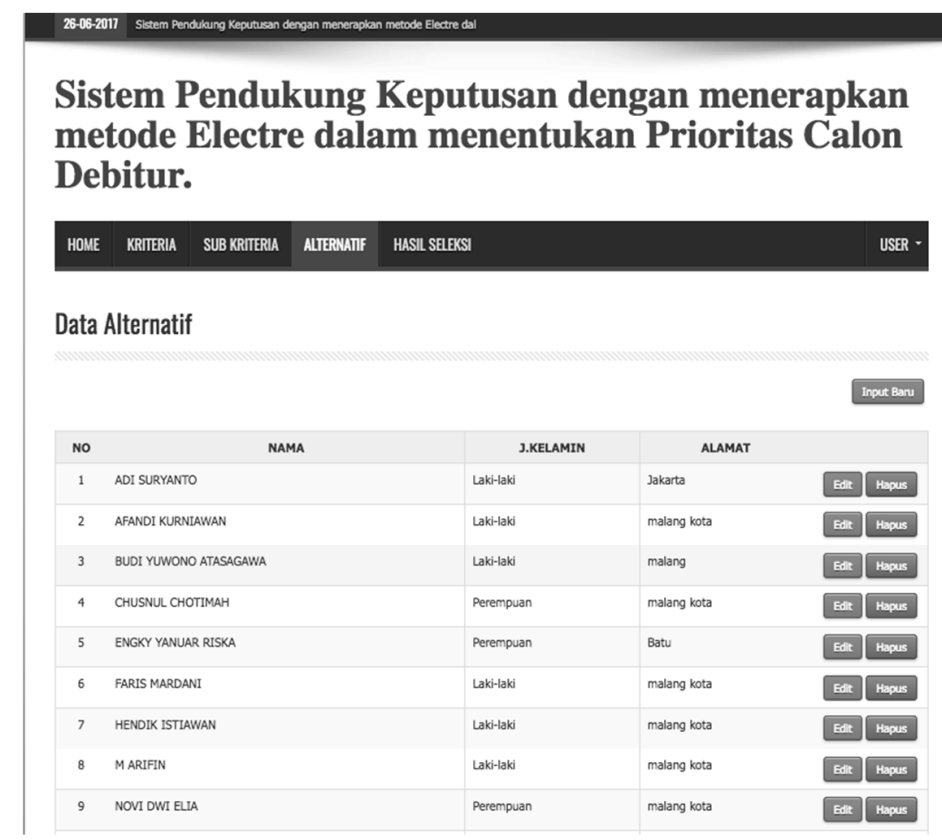

Gambar 13 Halaman data alternative 


\section{Halaman Hasil Seleksi}

Pada halaman hasil seleksi user dapat melihat hasil perhitungan dari metode Electre berdasarakan data-data alternatif yang telah diinputkan oleh user pada halaman alternatif. Pada halaman hasil selesi user dapat melihat beberapa informasi dan hasil perhitungan antara lain Tabel Rating kecocokan adalah tabel nilai berdasarkan nilai dari masing-masing kriteria yang telah dimasukkan oleh user, Bobot kriteria adalah bobot yang telah ditentukan oleh user, matrik ternomalisasi adalah hasil pembagian antara salah satu nilai kriteria dengan akar kuadrat dari total kriteria tersebut, Tabel $\mathrm{V}$ adalah hasil perkalian dari bobot salah satu kriteria dengan matrix ternomalisasi sehingga menghasilkan tabel hasil perangkingan yang merupakan hasil akhir dari perhitungan.

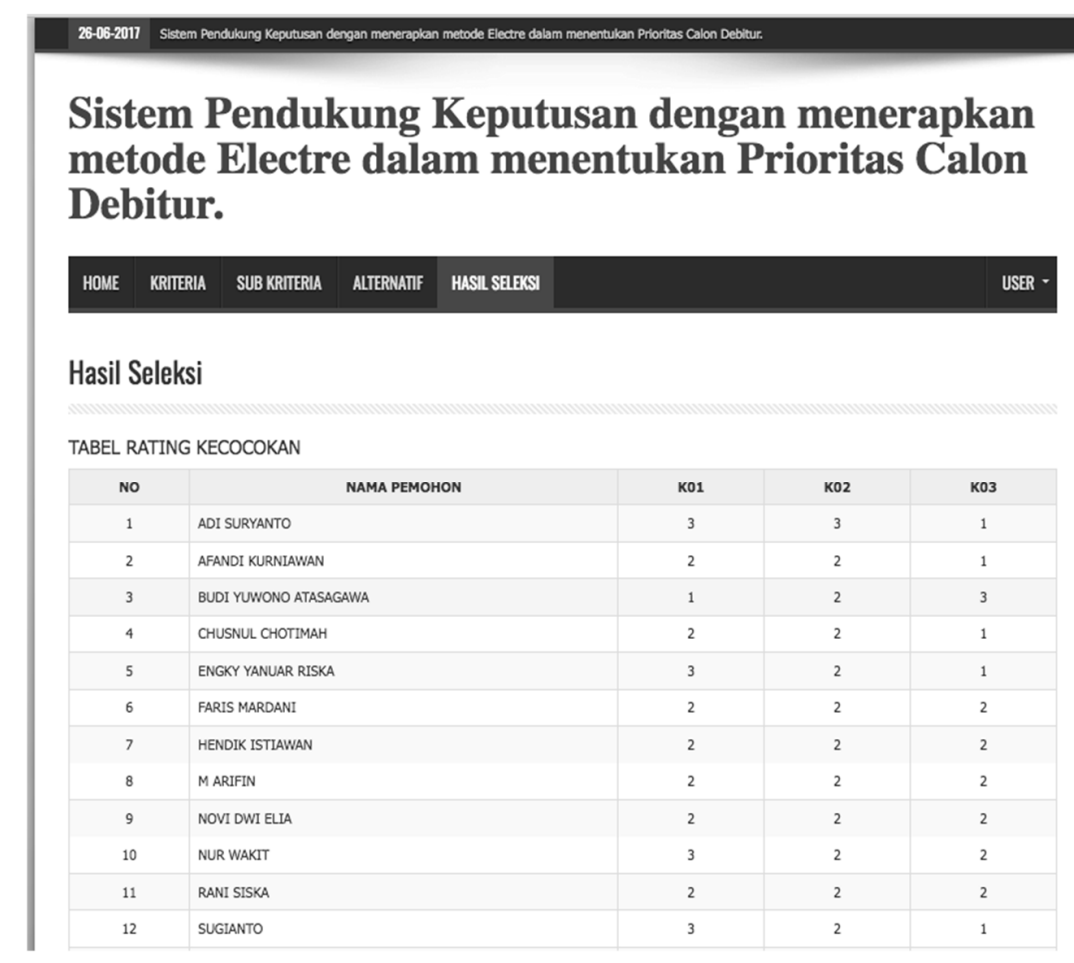

Gambar 14 Halaman hasil seleksi

\section{B. Pengujian}

Untuk mendapatkan hasil yang maksimal maka perlu adanya pengujian pada sisi aplikasi dengan memasukkan data pada halaman alternatif di mana sebelumnya user terlebih dahulu memasukkan nilai-nilai kriteria dan sub kriteria pada halaman kriteria dan pada halaman sub kriteria. Untuk pengujian data yang diinputkan sebanyak 15 data pada halaman kriteria. 


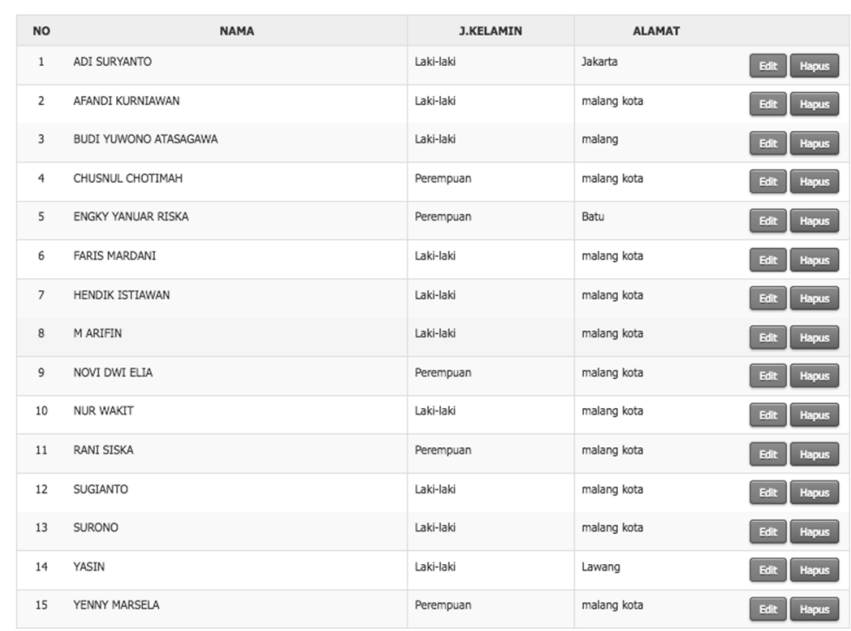

Gambar 15 Data alternatif

Pada halaman hasil seleksi user dapat dilihat hasil perhitungan dari metode Electre berdasarakan data-data alternatif yang telah dimasukkan oleh user pada halaman alternatif. Pada halaman hasil selesai user dapat melihat beberapa informasi dan hasil perhitungan antara lain Tabel Rating kecocokan adalah tabel nilai berdasarkan nilai dari masing-masing kriteria yang telah diinputkan oleh user, Bobot kriteria adalah bobot yang telah ditentukan oleh user, matrik ternomalisasi adalah hasil pembagian antara salah satu nilai kriteria dengan akar kuadrat dari total kriteria tersebut, Tabel $\mathrm{V}$ adalah hasil perkalian dari bobot salah satu kriteria dengan matrik ternomalisasi sehingga menghasilkan tabel hasil perangkingan yang merupakan hasil akhir dari perhitungan.

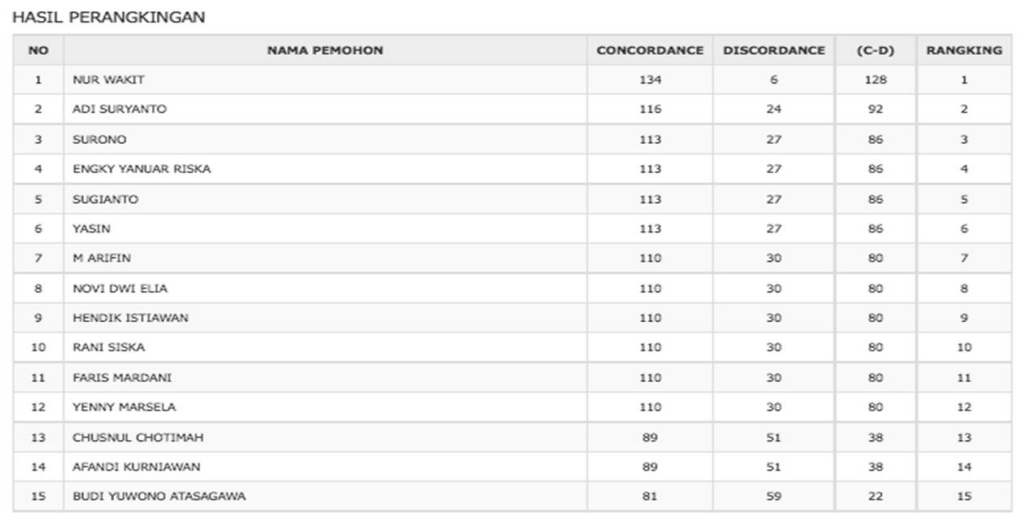

Gambar 16 Hasil Perangkingan 
Gambar 16 menunjukkan hasil bahwa Nur Wakit pada urutan pertama. Hal ini karena status rumahnya milik sendiri, penghasilan diantara 1-3 juta dan pekerjaannya pegawai swasta mendapatkan rangking pertama.

\section{A. Kesimpulan}

\section{KESIMPULAN DAN SARAN}

1. sistem penunjang keputusan menggunakan metode electre dapat membantu menentukan layak dan tidak berdasarkan kriteria-kriteria yang telah ditentukan oleh perusahaan.

2. Sistem dapat membantu user dalam mengambil keputusan untuk menentukan prioritas pinjaman dana tunai kepada calon nasabah yang tepat sehingga dapat meminimalisir resiko kredit.

\section{B. Saran}

Untuk penelitian selanjutnya dapat menggunakan metode Fuzzy AHP untuk proses perangkingan dan menambahkan beberapa kriteria-kriteria pendukung lainnya. Metode Fuzzy AHP adalah penggabungan 2 metode yang berbeda. Metode Fuzzy dapat digunakan untuk proses clustering dan metode $A H P$ dapat digunakan untuk proses klasifikasi.

\section{Daftar Pustaka}

Putra, Abner Adi, Desi Andreswari, dan Boko Susilo. 2015. Sistem Pendukung Keputusan untuk Penerima Bantuan Pinjaman Samisaki dengan Metode Electre (Studi Kasus: LKM Kelurahan Lingkar Timur Kota Bengkulu). Jurnal Rekursif. Vol 3 no 1.

Agustino, Addy Suyatno, dan Indah Fitri A. 2014. Sistem Pendukung Keputusan Pemilihan Kamera Digital SingleLensReflex Menggunakan Metode Elimination Et Choix Traduisant La Realite (ELECTRE). Jurnal Informatika Mulawarman. Vol. 9 No. 2 .

Anhar. 2010. Panduan Menguasai PHP \& MySQL. Jakarta : Media Kita.

Arief, M. Rudianto. 2011. Pemrograman Web Dinamis Menggunakan PHP dan MYSQL. Yogyakarta: Andi. 
Setiawan, Fahmi, Fatma Indriani, dan Muliadi. 2015. Implementasi Metode Electre Pada Sistem Pendukung Keputusan SNMPTN Jalur Undangan. Jurnal Ilmu Komputer. Vol. 02 No. 02.

Kusrini. 2007. Konsep dan Aplikasi Sistem Pendukung. Yogyakarta: Andi Offset.

Subakti, I. 2002. Sistem Pendukung Keputusan, Jurusan Teknik Informatika, Fakultas Teknologi Informasi. Surabaya: Institut Teknologi Sepuluh November.

Suryadi K. dan M. A Ramdhani. 1998. SistemPendukung Keputusan. Bandung:PT Remaja

Rosdakarya.

Turban, Efrain. 2005. Sistem Pengambil Keputusan dan Sistem Cerdas. Yogyakarta: Andi. 